Nutrient Dynamics and Retention in Land/Water Ecotones of Lowland, Temperate Lakes and Rivers.

(C) 1993 Kluwer Academic Publishers. Printed in Belgium.

\title{
A multi-pond system as a protective zone for the management of lakes in China
}

Chengqing Yin, Ming Zhao, Weigen Jin \& Zhiwen Lan

The Research Center for Eco-Environmental Sciences, Academia Sinica, P.O. Box 2871, Beijing 100085, P.R. China

Key words: multi-pond system, non-point pollution, ecotone, filtering effects

\begin{abstract}
A study was carried out in the small watershed of Chaohu Lake, where a scattered multi-pond system, as a part of the land-inland water ecotone, was found to be a good protective zone in the management of the lake. This multi-pond system can effectively reduce the non-point source load of nutrients, such as phosphorus and nitrogen from runoff water, and filter out sediments before they reach the lake. There are 150 artificial ponds in this small watershed, covering a surface area of 35.54 ha, which represents just under $5 \%$ of the whole catchment area. The nutrient retention in the first 9 months of the dry year 1988 was more than $90 \%$. This multi-pond system needs low capital cost and energy consumption for maintenance, and is suitable for irrigation and drainage, while it recycles water and nutrients within the terrestrial agroecosystem. As a result of this case study, a multipond system is being proposed as part of a long term management strategy for the watcrshed.
\end{abstract}

\section{Introduction}

Most lakes in China are shallow and eutrophic and nonpoint source nutrient loads account for more than half the total load (Jin et al., 1990). The reason can be traced back to a long history of civilization. Deforesting activities have changed large areas from natural forest vegetation to artificial farmland, and led to soil erosion in most cases (Yin \& Bernhardt, 1992). Besides, a large amount of fertilizer and a multi-cropping system are used for high production, to support a huge human population. As a result of these disturbances, the terrestrial ecosystem has become quite fragile and it has great impacts on the aquatic ecosystem (Novotny \& Checters, 1981; Ryding \& Rast, 1989). However, people can do very little to decrease their pressure on agricultural lands and reduce the use of fertilizer. Conversely, they are forced to further impact their fragile ecosystems, and increase their production to the limit of ecological irreversibility in an attempt to ensure their basic needs (Castri et al., 1988). This is a common problem faced by many developing countries.

A case study was carried out within the UNESCO Cooperative Ecological Research Project (CERP) to study the process of nutrients carried by surface runoff to a lake and what measures could be taken to reduce such loads (Yin \& Bernhardt, 1992).

A scattered multipond system in a small watershed was found to play a role in stabilizing both the terrestrial and aquatic ecosystem.

The multi-pond system is part of ancient Chinese culture, originally developed from single 
ponds above and below a hut or a village. Such ponds have existed for centuries (Needham, 1984) as drinking reservoirs for human and livestock. Later, farmers also used them for washing and fishing. With the development of agriculture, many ponds gradually linked up to become an irrigation network, which formed a characteristic agricultural landscape with ponds scattered among ricefields. Multi-pond systems mainly occur in rice cultivation areas in southern China, where permanent farm fields are numerous (Fig. 1).

The typical landscape of multipond systems is as follows: they lie mostly on the slopes of low hills and the plains, where rice cropping is the main type of land use. The typical ratio is usually one pond for one hectare of land; thousands of ponds in thousands of hectares of land form a large-scale irrigation and drainage network. The pond often have their own connections of ditches through which the overflow from the high elevation ponds can discharge to low elevation ponds without interfering with nearby rice fields.

\section{Study area, material and methods}

A study on the role of the multi-pond system in trapping nutrients and water to control non-point

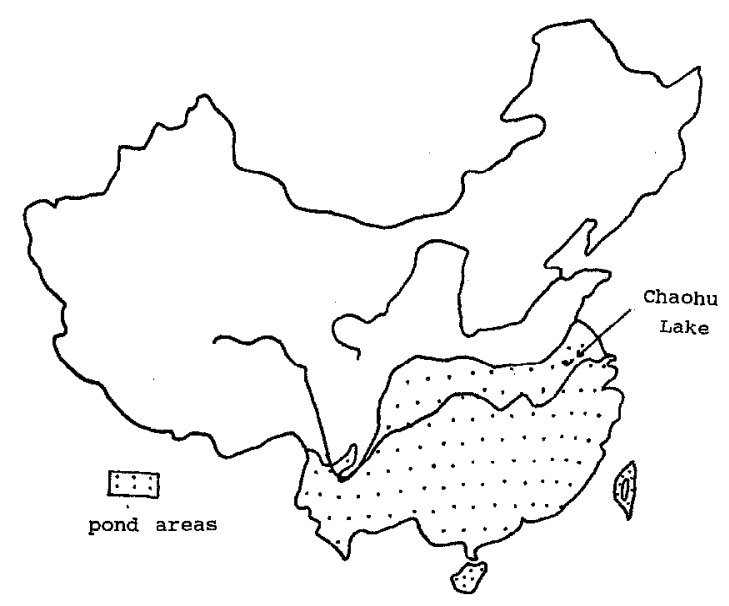

Fig. 1. Locations where multi-pond systems are widely used in China. source nutrient load was carried out in a small sub-watershed, Liuchahe, in the Chaohu Lake watershed (Yin et al., 1991).

Chaohu Lake, one of the five largest freshwater lakes in China, is located in Anhui Province, central China, on a tributary of the Yangtze River. It covers a surface area of $760 \mathrm{~km}^{2}$. Like most of the lakes in east and central China, it is quite shallow, with an average depth of only $3 \mathrm{~m}$. The original vegetation around the lake has been destroyed, giving way to agriculture and secondary forest growth. The lack of natural vegetation has resulted in erosion, particularly in the rainy seasons. In the recent modernization process, with rapid industrial development and heavy application of chemical fertilizers, nutrient-rich pollutants have drained increasingly into the lake, causing unprecedented lake eutrophication. This is now the most important environmental problem in Chaohu Lake (Tu et al., 1990). Therefore, restoration methods for the lake should concentrate on nutrient control within the watersheds (Solbe, 1986; Sas, 1989).

The two major causes for the eutrophication in Chaohu lake are point and nonpoint sources of nutrients. In our study, the nonpoint sources account for more than $50 \%$ of the total nutrient input (Tu et al., 1990). Point source pollution from cities and industry is relatively easy to control by waste water treatment plants and other engineering facilities, but nonpoint pollution from agricultural lands is difficult to reduce (Bernhardt \& Clasen, 1985). Thus, we attempted to control nonpoint pollution of Chaohu Lake.

Located on the northern bank of Chaohu Lake, the Liuchahe watershed covers an area of 732 ha and a resident population of about 3000 inhabitants, living in some 16 small villages. The social and economic situation of this sub-watershed is typical of that of a small-scale subsistence farming community. Like most of the area around the lake, a triple cropping system is used in the irrigated rice fields, consisting of early rice, late rice and rape. Non-irrigated farmland is cultivated normally with wheat, cotton, potatoes, corn, soybeans and other vegetables. The increasingly used fertilizers are usually chemical, but farmyard ma- 




Fig. 2. Land use of the Liuchahe sub-watershed.

nure and other domestic waste are also applied to the crop. There is no industry in Liuchahe subwatershed. Thus, all nutrients are derived from non-point sources.

The sub-watershed faces the lake in the southwest and is surrounded by low hills in the north and cast, to form a closed watershed with a clcar border. The highest elevation of the sub-watershed is $174.2 \mathrm{~m}$ above sea level and the lowest is an $8.5 \mathrm{~m}$ lowland protected by a dike (Fig. 2). The landscape and vegetation characteristics of the Liuchahe sub-watershed are similar to those of the whole lake watershed. The forestry area lies on the low mountain terraces; the nonirrigated farmland is situated on mounds; the villages normally lie around the top of the mounds; the rice fields and ponds are located in the plains or in the saddle between two mounds.

There are 150 artificial ponds within this small watershed, with a surfaced area of $35.5 \mathrm{ha}$, which is $4.86 \%$ of the whole catchment. These ponds store the runoff water and irrigate the rice fields. One or two ponds near the village are mainly used for daily washing. Only a few ponds at low ele- 
vation near the lake are used for fishery. The size of the ponds varies from a few hundred $\mathrm{m}^{2}$ to about one hectare. Their depth is about $1.5 \mathrm{~m}$. In dry season, they can dry out to bottom. In flood season, they can be full and their depth can reach 2 to 2.5 meters. The ponds on the hills have a more variable depth, and there are no or few species of macrophyte vegetation. The ponds on the plain have a more constant water level and have vegetation of standing, submerged and floating macrophytes.

The land use composition in Liuchahe watershed is as follows: rice field 284.3 ha $(38.8 \%)$, nonirrigated farm land 228.9 ha (31.3), forest 131.0 ha $(19.9 \%)$, ponds 35.5 ha $(4.86 \%)$ and villages 52.2 ha $(7.1 \%)$.

Nearly one year of monitoring of nitrogen $(\mathrm{N})$ and phosphorus $(\mathrm{P})$ concentrations in runoff waters of different areas within the Liuchahe subwatershed was carried out for the identification of contributions of nonpoint source pollution in 1988. Additional monitoring was carried out in the fall of 1987 and spring of 1989 . Samples were taken from 15 ponds, 10 wells, 8 points in one stream, 9 pieces of rice fields, 4 plots of dry agricultural land and 2 plots in wooded tracts. Water samples from the rice fields and the ponds were taken every 15 days. Water samples from the stream were taken after each rainy day. Runoff water samples were taken only after rainfall when runoff existed. The soil and pond sediment samples were taken in September 1988.

Water samples were treated within 2 hours after sampling in a nearby field laboratory. The water samples were digested with $\mathrm{K}_{2} \mathrm{~S}_{2} \mathrm{O}_{7}$ solution for determination of dissolved and total $\mathbf{N}$ and $\mathrm{P}$ (Ebina et al., 1983). The flow rate of the stream water was determined with a flowmeter and was measured every 15 days or after rainfalls, while the cross-section area was mcasured.

\section{Results}

Nonpoint source of nutrients in the sub-watershed

A rice field is a potential source for nonpoint nutrient load, especially in the months of May and August. There are high concentrations of $\mathrm{N}$ and $\mathrm{P}$ in the flooding water of rice fields with total nitrogen (TN) and total phosphorus (TP) ranging from $0.2-107 \mathrm{mg} \mathrm{l}^{-1}$ and $0.05-0.75 \mathrm{mg} \mathrm{l}^{-1}$, respectively (Fig. 3).

Vegetable fields are another important source for nonpoint nutrient load. Normally each family has one or two vegetablc plots for daily family consumption. Liquid household manure, such as dung, is often applied, so that the soil and its surface runoff have a higher $\mathrm{N}$ and $\mathrm{P}$ content. As vegetable plots occupy only a small portion of land, their contribution to the nonpoint nutrient load is limited (Fig. 3).

The nonirrigated farmland (crop field - Fig. 3) must be emphasized as it generates most of the runoff volume with a high concentration of nutrients and sediments from soil erosion. The output of eroded nutrients and sediments is strongly influenced by fertilizing and crop growth stages, because farmyard manure is applied to these nonirrigated fields while the crops are being transplanted. Thus the important period lies between the harvest of one crop and the planting of the next. Less coverage may cause soil erosion at suitable rainfall intensity during the seedling stage.

The nonpoint nutrient load from forested hills is low compared to other land uses (Fig. 3).

Quite lower $\mathrm{N}$ and $\mathrm{P}$ concentrations appear in pond and canal runoff, even lower than the $\mathrm{N}$ and $\mathrm{P}$ concentrations in Chaohu Lake (Fig. 3).

\section{Water storage in ponds}

The pond water storage capacity is calculated from multiple surface area and depth of ponds. The ponds have a total volume of $710800 \mathrm{~m}^{3}$ and can store as much as $97 \mathrm{~mm}$ of rainfall falling on the whole 732 ha catchment, if all water flows into these ponds.

During 1988, the first flow with $17330 \mathrm{~m}^{3}$ runoff appeared on March 15, after a three-day rainfall (4.7 mm on March 13,19.8 mm on March 14 and $14.23 \mathrm{~mm}$ on March 15). Until that time, there had been about $174 \mathrm{~mm}$ of precipitation, 




Fig. 3. TP and TN concentrations (annual average) in surface runoff waters from different land use areas, including ponds and the lake.

with $126.9 \mathrm{~mm}$ of snowfall in January and February, and $47.5 \mathrm{~mm}$ of rainfall in the first half of March. There was no runoff during April of 1988 because during that whole month precipitation was only $27.2 \mathrm{~mm}$. According to the average value in the last 24 years, normal rainfall in April is $104.0 \mathrm{~mm}$. The first half of May is the time to use pond water for ploughing, harrowing rice fields, and for transplanting early rice seedling after rape harvest at the end of April. Usually a water depth of about $20 \mathrm{~cm}$ is needed for the preparation of a rice field. There are $2842800 \mathrm{~m}^{2}$ of rice fields. These consumed $568560 \mathrm{~m}^{3}$ of pond water, or $80 \%$ of total pond water storage.

From May 15 to June 29, there ware $163.9 \mathrm{~mm}$ of rainfall and the second discharge with a $9930 \mathrm{~m}^{3}$ flow into Chaohu Lake occurred only for three days after the rainfall event $6.3 \mathrm{~mm}$ on June $27,55.5 \mathrm{~mm}$ on June 28 and $2.1 \mathrm{~mm}$ on June 29). Because the enclosed boundary banks of rice fields can store a depth of $5-10 \mathrm{~cm}$ water within the fields, and as $0.7-1.0 \mathrm{~cm}$ depth of field water is lost by evaporation, transpiration and percolation on each sunny day, the watershed storage capacity was enlarged and the runoff decrease in comparison with the first canal discharge on March 15.

In July of 1988 , there was only $52.7 \mathrm{~mm}$ of rainfall with $20 \mathrm{~mm}$ in July 24 , and $24.8 \mathrm{~mm}$ on July 25 , which caused no runoff. Normally July 
has the highest rainfall with an average of $161.4 \mathrm{~mm}$. Because of a drought in 1988, about $117900 \mathrm{~m}^{3}$ water were pumped from Chaohu Lake to the irrigation networks, ponds and rice fields during July.

Early rice was harvested at the end of July and late rice seedling were transplanted in early August. Therefore, a large amount of water was needed. Even though there were $121.4 \mathrm{~mm}$ of total rainfall, with $35.6 \mathrm{~mm}$ on August 8, $22.1 \mathrm{~mm}$ on August 19, and $14.9 \mathrm{~mm}$ on August 20, $21.8 \mathrm{~mm}$ on August 25, and $25.3 \mathrm{~mm}$ on $\mathrm{Au}-$ gust 26 , there was no canal discharge at all during August.

It was not until September, after the rice fields had been drained for sun-drying to adjust the paddy soil moisture for winter rape growth, that the third canal discharge occurred on September 9, with $480 \mathrm{~m}^{3}$ of flow following a two-day rainfall (25.6 $\mathrm{mm}$ on September 8 and $4.4 \mathrm{~mm}$ on September 9). The last $370 \mathrm{~m}^{3}$ flow happened on September 14, after a $18.8 \mathrm{~mm}$ rainfall event. These two small canal runoffs mainly came from rice fields near the canal because the closed boundary banks had been opened for the sundrying period.

From January to September, there were $676 \mathrm{~mm}$ of precipitation that caused only $28110 \mathrm{~m}^{3}$ of flow to Chaohu Lake. With the weighted average runoff coefficient 0.19 of the whole sub-watershed area, this is only $3.0 \%$ of the total rainfall runoff from this catchment area. The rest is supposed to be stored in the ponds and consumed by croplands.

Nutrient concentration in ponds in relation to their localization

It was found that ponds at a foothill have sediments with the lowest nutrient but high sand and gravel content, because no fertilizer is applied to these sandstone hills. Villages are more strongly affecting the nearby ponds, where nutrient concentration in sediment is high. Ponds surrounded by nonirrigated fields have higher organic matter
(OM) and total $\mathrm{P}$ content in sediment, because most of the farmyard manure is applied to nonirrigated fields.

Water samples were collected from ponds, canal discharges and Chaohu Lake during 1988. Table 1 gives the nitrogen and phosphorus concentration in ponds of different localization, canal discharge, and the lake.

The concentrations of TN and TP in ponds are lower in winter and spring (from October to April), higher in summer (from May to July), and highest in autumn (from August to September) (Table 1).

Ponds which are surrounded by nonirrigated dry farmland and ponds which are located at the foot of a hill have the highest TN and TP concentration.

Ponds among rice fields have two peaks of TN and TP concentrations: one in early May because of the influence of early rice seedling transplantation, and the other in mid September, when the rice fields are drained (Tab. 1).

When compared to concentrations of TN and TP in other rivers and in Chaohu Lake (Tu et al., 1990), the study area has lower TN and TP concentrations in its canal discharge. TN in runoff of other rivers is $1.0 \mathrm{mg} \mathrm{l}^{-1}$. This means that the Liuchahe watershed has little influence on Chaohu Lake eutrophication.

\section{Reduction in nutrient concentration in canal discharge to Chaohu Lake}

Besides ponds scattered in the agricultural fields and at the foothill, there are several ponds along the canals of the Liuchahe River. These ponds have a direct influence on the nutrient concentrations in the stream outflow to the lake. In the rainfall event during June 27 to 29,1988 , the theoretical runoff value calculated according to measured concentrations in runoff from different land use types should have nutrient concentrations of $1.54 \mathrm{mg} \mathrm{N}^{-1}$ and $0.095 \mathrm{mg} \mathrm{P}^{-1}$. But the concentration in the stream outflow was only $0.31 \mathrm{mg} \mathrm{N}^{-1}$ and $0.042 \mathrm{mg} \mathrm{P}^{-1}$, which was 
Table 1. Average concentratin of TN (upper values) and TP (lower values) in $\mathrm{mg} \cdot \mathrm{m}^{-1}$ in two or three ponds of various lacations and in the canal and the lake.

\begin{tabular}{|c|c|c|c|c|}
\hline \multirow[t]{2}{*}{ Period } & \multicolumn{3}{|l|}{ Ponds: } & \multirow{2}{*}{$\begin{array}{l}\text { Lake } \\
\text { Chaohu }\end{array}$} \\
\hline & $\begin{array}{l}\text { among } \\
\text { rice fields }\end{array}$ & $\begin{array}{l}\text { near } \\
\text { village }\end{array}$ & $\begin{array}{l}\text { near } \\
\text { village canal }\end{array}$ & \\
\hline
\end{tabular}

Feb. 22-25

\begin{tabular}{|c|c|c|c|c|c|c|}
\hline \multirow{2}{*}{ Apr. 20} & 0.234 & 0.272 & 0.527 & 0.195 & 0.393 & 0.223 \\
\hline & $\overline{0.064}$ & $\overline{0.058}$ & $\overline{0.066}$ & $\overline{0.062}$ & $\overline{0.094}$ & $\overline{0.050}$ \\
\hline May 5 & & $\frac{0.667}{0.099}$ & & & & $\frac{0.552}{0.035}$ \\
\hline
\end{tabular}

May $8-10$

May 14

$\frac{0.430}{0.037}$

$\frac{0.333}{0.052}$

Jun. 3

July 1

$\frac{0.613}{0.135} \quad \frac{0.416}{0.051}$

Aug. 6-10

Sept. 11

$\frac{3.553}{0.128}$

$\frac{1.191}{0.044}$

$\frac{0.925}{0.050}$

$\frac{0.891}{0.042}$

$\frac{0.652}{0.044}$

$\frac{0.584}{0.035}$

$\frac{0.396}{0.231}$

$\frac{0.189}{0.020}$

Oct. 15

$\frac{0.288}{0.135}$

Nov. 3-6

Average

$$
\frac{1.394}{0.112}
$$

$\frac{0.598}{0.052}$

$\frac{0.592}{0.093} \quad \frac{0.426}{0.049}$ $\frac{2.320}{0.155}$

$\frac{1.700}{0.144}$

$\frac{0.685}{0.018}$

$\frac{0.971}{0.102} \quad \frac{0.422}{0.072}$

$\frac{0.910}{0.097}$

$\frac{4.902}{0.094} \quad \frac{0.754}{0.056}$

$\frac{3.297}{0.116}$

$\frac{0.214}{0.085}$

$\frac{1.580}{0.114}$

$\frac{2.391}{0.102}$

0.475

$\frac{1.680}{0.127}$ less than half of the calculated mixed runoff from the land. This results shows that the retention of nutrients in surface runoff by the multi-pond sys$\mathrm{tcm}$ is quite noticcable. The nutrient changes in canal ponds also reflect the agricultural activities in the catchment area, the rainfall events and their possible influences on canal discharges and nonpoint pollution to Chaohu Lake.
Retention of nutrients by the multipond system

Because of the effects of water storage and nutrient concentration reduction, nutricnts arc rctained in the multipond system. The retention rate can be calculated by the following formula:

$$
R=\frac{L_{c}-\left(C_{m} \times F_{m}\right)}{L_{c}}
$$


where $R$ is the retention rate,

$L_{c}$ is calculated nutrient load based on measured nutrient concentrations on different land use types and their runoff coefficients,

$C_{m}$ is the measured nutrient concentration at the stream mouth with the lake,

$F_{m}$ is the measurcd strcam flow rate in volume.

The retention rate calculated for the first 9 months of 1988 is $99 \%$ for nitrogen and $98 \%$ for phosphorus, respectively.

\section{Discussion}

Before the surface runoff discharges to Chaohu Lake from the Liuchahe catchment area, it flows through a series of ponds located at the hill foot, the nonirrigated farmland and the rice fields, and finally flows through a small canal to Chaohu Lake. In pond after pond, most of the sediment and nutrients and water from surface runoff after rainfall events are intercepted and stored inside the watershed. The water and nutrients can easily be reused for irrigation of rice fields and other farm land. To build a multi-pond system, one only needs small labor investment and some area. It needs little money and no electric power to run and manage this system. From this study we can conclude that a well designed multi-pond system which depends on the following factors:

(a) annual rainfall amount and its distribution,

(b) watershed water storage capacity,

(c) land use types, their locations and their water consumptions,

can be used to control nonpoint source pollution from the catchment of lakes in southern China.

Chaohu Lake and its surrounding area are dynamic components of aquatic and terrestrial landscapes. The whole ecosystem can be viewed as a collection of resource patches separated by boundaries or ecotones. The ecotone, acting as a semipermeable boundary separating adjacent ecosystems (Naiman et al., 1988), plays an important role in controlling mass flows of sediments and nutrients in landscape processes. It can act as a barrier, impeding the transit of nutrients (Hansen et al., 1988a, Hansen et al., 1988b).

These tiny ponds can be considered as the front of an aquatic ecosystem against a terrestrial ecosystem. Energy and material are frequently exchanged within the ponds and their surrounding land. The multi-pond system, as part of the land-water ecotone is analogous to a membrane, and has filtering effects. Such a function in the Liuchahe sub-watershed can be seen in Fig. 4,

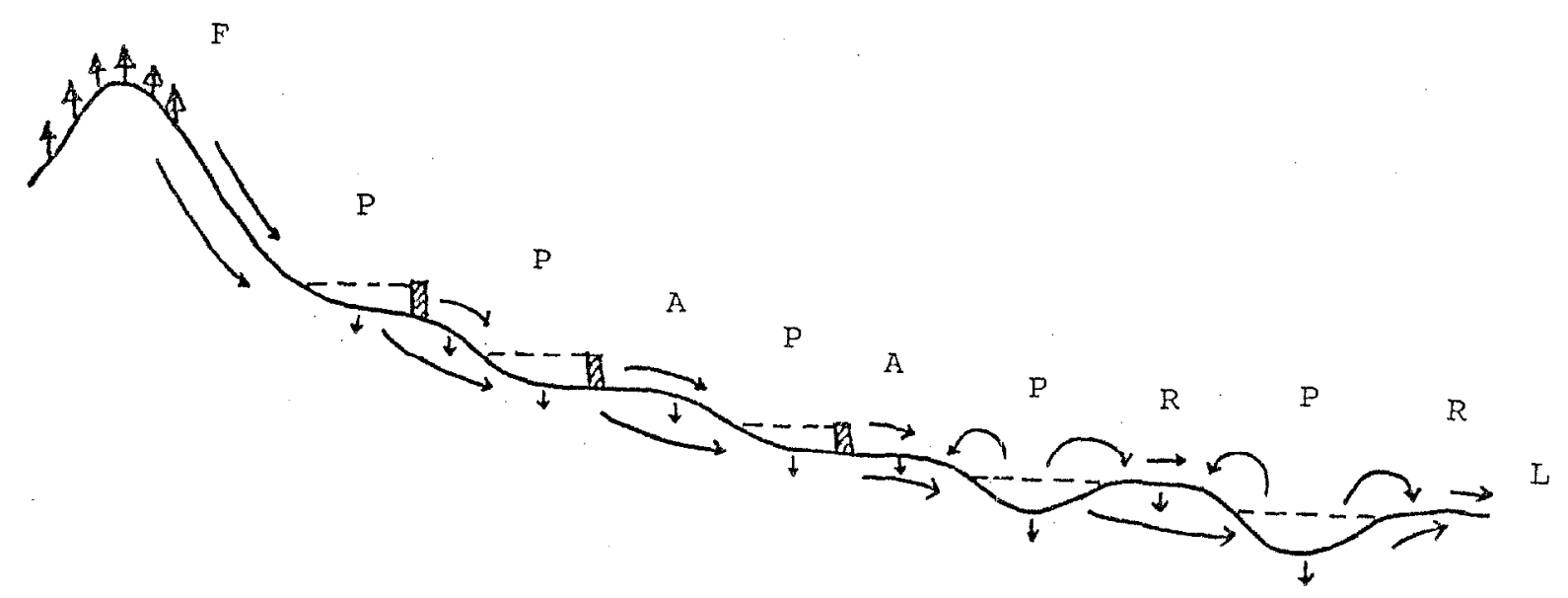

Fig. 4. The filtering effect diagram for nutrient dynamics in a multi-pond system. F: forest, P: pond, A: dry agriculture land, R: rice field, L: lake. The arrows indicate the direction of water use or flow. 
which shows how nutrient flows are filtered and trapped by a multi-pond system.

The runoff water with erodes materials enters ponds at higher elevations in the hillfoot. Water can be used by surrounding land for irrigation while drainage water flows back to the pond or to a pond at a lower elevation. Since rice usually needs frequent irrigation, water in the system is reused several times before it reaches the main river channel. In such a flow and cycling process, most nutrients can be kept in the terrestrial ecosystem.

\section{Conclusion}

It was shown in this study, that the multi-pond system, being part of a land-inland water ecotone, has storage effects for runoff water and filtering effects for nutrients. This multi-pond system needs low capital cost and energy consumption of maintenance, and is suitable for irrigation and drainage while it recycles water and nutrients within the agroecosystem. It should be included in a long-term management strategy for the watershed, to prevent non-point source pollutants and sediments from being discharged into larger lakes.

\section{Acknowledgements}

This work was performed as part of the Cooperative Ecological Research Project (CERP) sponsored by the Federal Ministry for Research and Technology of the Federal Republic of Germany, the Academy of Science of the People's Republic of China, and the 'Man and the Biosphere' Programme of UNESCO. The authors are grateful to the Hefei Environmental Monitor Station for assistance in the analysis of samples.

\section{References}

Bernhardt, H. \& J. Clasen, 1985. Recent developments and perspective of restoration for artificial basins used for water supply. Lake Pollution and Recovery International Congress: European Water Pollution Control Association, Proceedings, Rome. 15-18.

Castri di, F., A. J. Hansen \& M. M. Holland, 1988. Preface. Biology International, Special Issue 17: 1-8.

Ebina, J., T. Tsutsui \& T. Shirai, 1983. Simultaneous determination of total nitrogen and total phosphorus in water using peroxodisulfate oxidation. Wat. Res. 17: 1721-1726.

Hansen, A. J., F. di Castri \& R. J. Naiman, 1988a. Ecotones: What and why. Biology International, Special Issue 17: 9-46.

Hansen, A. J., F. di Castri \& P. G. Risser, 1988b. A New Scope Project. Ecotones in a changing Environment: The Theory and management of landscape boundaries. Biology International, Special Issue 17: 137-161.

Holland, M. M., 1988. SCOPE/MAB technical consultations on landscape boundaries. Report of a SCOPE/MAB workshop on ecotones. Biology International, Special Issue 17: 47-106.

Jin, X., H. Liu, Q. Tu, Z. Zhang \& X. Zhu, 1990. Lake eutrophication in China. Environmental Sciences Press of China (in Chinese). 1-5, 103-115.

Naiman, R. J., M. M. Holland, H. Decamps \& P. G. Risser, 1988. A new Unesco Programme: Research and management of land/inland water ecotones. Biology International, Special Issue 17: 107-136.

Needham, J., 1984. Science and civilization in China: Agriculture. Cambridge: The University Press. 1-9, 495-510.

Novotny, V. \& G. Chesters, 1981. Handbook of nonpoint pollution: source and management. Van Nostrand Reinhold Company. $555 \mathrm{pp}$.

Ryding, S.-O.\&W. Rast, 1989. The control of eutrophication of lakes and reservoirs. Man and The Biosphere Series. UNESCO, Paris \& The Parthenon Publishing Group. 314 pp.

Sas, H., 1989. Lake restoration by reduction of nutrient loading. Academia-Verl. Richarz. 497 pp.

Solhe, I. F. de., 1986. Fffects of land use on fresh waters: agriculture, forestry, mineral exploitation, urbanization. Ellis Horwood Limited Publishers, Chichester. 568 pp.

Tu, Q., D. Gu, C. Yin, Z. Xu \& J. Han, 1990. Chaohu Lake eutrophication study. University Press of Science and Technology of China (in Chinese). $226 \mathrm{pp}$.

Yin, C., W. Jin, Z. Lan \& M. Zhao, 1991. Chaohu Lake eutrophication and nutrient load reduction. Verh. int. Ver. Limnol. 24: 1086-1087.

Yin, C. \& H. Bernhardt. 1992. A case study of shallow and eutrophic lakes in China. Journal of Environmental Sciences (China) 4 (2): 5-16. 